\title{
Elections, recession expectations and excessive debt: an unholy trinity
}

\author{
Frank Bohn ${ }^{1}$ (D) Francisco José Veiga ${ }^{2}$
}

Received: 2 November 2017 / Accepted: 5 February 2019 / Published online: 19 February 2019

(c) The Author(s) 2019

\begin{abstract}
In the literature, it has been suggested that political budget cycles are context-conditional, i.e., do not occur in all countries or under all circumstances. What about the underlying economic conditions? It has already has been shown that recessionary expectations reinforce the political budget cycle. This paper argues theoretically that opportunistic policymakers expecting a recession during an election year allow the primary deficit to increase even more when the stock of debt is very high, but reduce the deficit by more during an expected boom (in an election year). For the empirical estimation we use panel data from Portuguese municipalities. Plots of average marginal effects for election years show that differences between high- and low-debt municipalities become more pronounced in stronger expected recessions as well as booms; the stronger effect on the deficit in highdebt municipalities is caused by changes on both the revenue and the expenditure side. A whole armada of robustness tests (non-linear effects, alternative specifications of excessive debt and forecasts, various methods to account for time effects and clustering, several sample restrictions) confirms our results.
\end{abstract}

Keywords Political budget cycles · Countercyclical policies $\cdot$ Government deficit $\cdot$ Political opportunism $\cdot$ Local governments $\cdot$ Portugal

JEL Classification D72 $\cdot$ E32 $\cdot$ E62 $\cdot$ H62 $\cdot$ H63

Electronic supplementary material The online version of this article (https://doi.org/10.1007/s1112 7-019-00647-x) contains supplementary material, which is available to authorized users.

Frank Bohn

f.bohn@fm.ru.nl

Francisco José Veiga

fjveiga@eeg.uminho.pt

1 Department of Economics, Institute for Management Research, Radboud University, Heyendaalseweg 141, 6525 AJ Nijmegen, The Netherlands

2 Escola de Economia e Gestão, Universidade do Minho and NIPE, 4710-057 Braga, Portugal 


\section{Introduction}

It is seen as a stylized fact that political budget cycles (PBCs) are context-conditional, i.e., they do not occur in all countries or under all circumstances. Early on it was argued that PBCs are more likely to appear in specific country groups, e.g., developing countries (Schuknecht 1996) or new democracies (Brender and Drazen 2005). The emphasis then shifted to country characteristics like fiscal intransparency (Alt and Lassen 2006) or the electoral system (Aidt and Mooney 2014). Veiga et al. (2017) confront several of those conditioning factors and find that media freedom is key in reducing the incidence of PBCs. Bohn and Veiga (2017) move the focus to economic conditions and present evidence showing that recessionary expectations reinforce the political budget cycle.

This paper deepens the analysis of the effects of economic conditions on PBCs. It argues that local public sectors (e.g., in countries, municipalities) with high stocks of debt may end up with larger primary deficits in election years than those with smaller initial debts when a recession is expected (and vice versa for expected booms). That prediction is relevant for two reasons. First, high-debt governments face recessions frequently. Second, the high deficit outcome may seem surprising because high-debt local governments are often pressured, if not obliged, to raise tax or other revenues, cut expenditures, or both, in order to produce primary surpluses or, at least, to reduce their primary deficits dramatically (for instance, in order to reach pre-set debt targets). During a recession, such actions may not be easy. It likewise may not be desirable; standard Keynesian countercyclical policies may be adopted to alleviate the macroeconomic consequences of the recession. However, efforts to improve primary balances should be at least as strong in the presence of high debt stocks as not. In fact, that is the (normal) government response to a high stock of debt in an expected recession in an off-election year. But why, then, is the primary deficit larger in high-debt governments when a recession is expected in an election year?

Our answer is very simple and we illustrate it in an opportunistic PBC model that incorporates boom and recession expectations. Our model shows that an opportunistic policymaker is immune to debt targets (including a potential reputational loss) when a recession is expected during an election year. Instead, such a policymaker is concerned about her electoral prospects, which improve if voters can be made to believe in her competence. Such beliefs, in turn, depend on whether the policymaker is able or not to raise public services provision or expenditures by more than what voters expect. If so, the larger primary budget deficit in a high-debt government (in an election year when a recession is expected) is due entirely to the fact that a government of a highly indebted public sector typically must impose higher tax rates than otherwise and, therefore, loses more tax revenue during a recession. To undo that loss, and still appear competent, an opportunistic policymaker of a high-debt government has to accept a larger primary deficit. The opposite argument holds for expected boom times; an opportunistic policymaker then can plan on using the larger tax revenues to reduce the stock of outstanding debt without compromising her reelection chances.

Our logic works when excessive debt coincides with higher tax rates. But that is not guaranteed. In fact, excessive debt may have been produced because tax rates were too low in the first place. Eventually, excessive-debt governments will have to impose high tax rates or cut spending drastically to tackle the debt problem. It may be difficult to judge whether a public sector is still in the rapid debt accumulation, low tax-rate phase or in the excessive debt, high tax-rate phase. That is so because it is not at all obvious what constitutes a high tax rate. At a country level, for instance, tax rates depend on specific factors 
like the development of the tax system, the cost of tax enforcement (which depends, for instance, on the share of the agricultural sector in total output), or the willingness and ability of policymakers to use seigniorage. ${ }^{1}$ At a sub-national level, the institutions of public finance tend to be more coherent, i.e., tax rates and procedures for responding to excessive debt are much the same, especially if procedures are in place for dealing with the latter. The Portuguese municipal data employed in this paper satisfy those conditions. We do not have tax rate data for most of our sample period, but we discuss in Footnote 18 and show in the Online Appendix that public revenues tend to be larger in high, excessive-debt municipalities.

The empirical results, obtained for a sample composed of all Portuguese municipalities covering the 2002-2014 period, confirm the intuition that our model suggests robustly. Based on our regression results, we illustrate policy changes in election years over forecasted growth rates with plots of average marginal effects. Those marginal effect plots show larger primary budget deficits in high-debt municipalities during expected recession times and smaller primary deficits during expected booms (compared to low- debt municipalities). The difference rises for expectations of more serious recessions as well as for expectations of more pronounced booms.

Our results extend the discussion of context-conditionality for political budget cycles. The evidence shows that excessive debt, if paired with high tax rates, produces even stronger PBCs during recessionary periods. It captures an important mechanism with significant policy implications. In particular, the findings say that it may even be counterproductive to prescribe harsh medicine (higher tax rates), if the excessive-debt government faces frequent elections during recessionary periods. Another interpretation relates to the role of fiscal constraints in the emergence of political budget cycles. Streb et al. (2009) discuss checks and balances that serve as institutional constraints for reducing political budget cycles. This paper argues that the existence of small public debts are by themselves constraints that limit political budget cycles (at least during recessionary periods).

We emphasize recessions and excessive debt as conditioning factors herein, but other conditionalities likewise may play roles (see reviews by Franzese 2002; de Haan and Klomp 2013). First, we focus on the aggregate level of fiscal policy in terms of the primary deficit, but not on particular types of expenditures. ${ }^{2}$ In a robustness test, we also present results for total expenditures and fiscal revenues. Footnote 19 explains why such evidence provides clues in the direction of the results we obtain for primary deficits. Second and consequently, we do not account for fiscal ideologies. Given that we find a significant PBC effect, no overall fiscal conservatism arguably is evident, as suggested by Pelzman (1992). ${ }^{3}$ We can, however, not exclude the possibility that the PBC effect occurs because policymakers manipulate certain

\footnotetext{
1 At the country level, we would also not be able to avoid having to define excessive debt in an ad-hoc way. For most countries, there are no legal public debt limits. Even if they exist, they are typically not binding. The EU fiscal rules, for instance, did establish a limit of $60 \%$ of GDP for the gross public debt of member countries, but it was not binding for entering the Eurozone and only received greater importance with the changes in the rules after the sovereign debt crisis.

2 The notion of cycles in various types of public expenditures is supported by, for instance, Schuknecht (2000) for capital expenditures, Drazen (2001) for transfers, Block (2002) for visible current expenditures and Vergne (2009) for subsidies. Cycles in the composition of expenditure also are suggested, for instance, by Veiga and Veiga (2007), Drazen and Eslava (2010), Schneider (2010) and Aidt and Mooney (2014).

3 And empirically supported by Hayo and Neumeier (2017) for Germany, Drazen and Eslava (2010) for Colombia, and Brender and Drazen (2008) for a panel of countries. Moreover, Veiga and Veiga (2007) and Aidt et al. (2011) find no fiscal conservatism in Portuguese municipal voting.
} 
types of expenditures (which we do not distinguish in the paper) in favor of some key groups of voters.

Our theoretical model likewise does not distinguish between different types of expenditures or voters. It presupposes that voters do not behave as fiscal conservatives, either because they do not want to or because budgetary manipulation is so effective that it overcompensates any fiscally conservative predisposition. The opportunistic political budget cycle model we use implicitly assumes that voters, rational or not, actually can be made to believe in the competence of incumbent policymakers. It was Rogoff and Sibert's (1988) and Rogoff's (1990) idea that utility-maximising voters should be concerned only about the competence of the policymaker chosen for governing after the elections. If competence shocks are persistent (usually modelled as MA(1) shocks), the task of voters becomes one of competence extraction in deciding for whom to vote. However, even rational voters can be fooled in the presence of informational asymmetry. In Rogoff's world, politicians observe their own competence skills before voters do; hence, we obtain a signalling model. In the Lohmann (1998) and Shi and Svensson (2006) world, some part of the electorate is uninformed or has some other handicap; in Bohn and Veiga (2017), it is inertial growth perceptions. It is important, however, that politicians cannot observe their own competence shocks. No signalling is thus possible; instead, the incumbent will exert some hidden effort to manipulate the outcome of the elections. Our model is in the latter pure moral-hazard tradition.

The paper is structured as follows. Section 2 lays out the model. Indications of the solution and the main results can be found in Sect. 3. Section 4 describes the data, the institutional setting, and the empirical model. Section 5 presents empirical evidence (including the results of robustness tests) providing support for the main implications of the theoretical model. Section 6 concludes.

\section{Model}

The model combines elements from Lohmann (1998), Shi and Svensson (2006) and Bohn and Veiga (2017). It captures an economy with $n$ voters and two opportunistic candidates, an incumbent and a challenger, who compete for holding office every alternate period. Each agent's expected utility depends on the discounted present value of expected per-period utilities which, in turn, consist of additively separable economic and political utilities ( $\beta$ is the discount factor; $E$ is the expectations operator). In each period, voters derive utility from consumption $c\left(u\left(c_{s}\right)\right)$, which has the standard concavity properties, from local public goods $L$ and from political utility $\theta^{i} z_{s}$ (with weight $\alpha$ ). Voter $i$ 's ideological preference or personal sympathy, $\theta^{i}$, is distributed uniformly over the interval $[-1,1] ; z$ indicates who is in power $\left(z_{s}=-\frac{1}{2}\right.$, if $a$ is in power; $z_{s}=\frac{1}{2}$, if $b$ is in power; without limiting the generality of the analysis we call $a$ the incumbent and $b$ the challenger). If her favorite candidate is in power, voter $i$ receives positive political utility; political utility is smaller for more moderate voters, i.e., voters with weaker views on the candidates' competencies. Voters vote prospectively in that they choose the candidate who can deliver the highest expected utility in the future. More moderate voters might, therefore, vote for the "wrong" candidate, if they are compensated by higher economic utility. The voters' utility function is:

$$
U_{t}^{i}=\sum_{s=t}^{\infty}\left(\beta^{i}\right)^{s-t} E_{t}\left[u\left(c_{s}\right)+L_{s}+\alpha \theta^{i} z_{s}\right] ; \quad s=t, t+1, \ldots ; \quad i=1, \ldots, n .
$$


The candidates' economic utility is the same as the voters'. However, candidates receive a political (dis-)utility only if they are in office: an ego rent and a potential reputation loss, if they also were responsible for missing pre-set debt target $B_{s-1}^{*}$ (see further down) in the previous year:

$$
\begin{gathered}
V_{t}^{j}=\sum_{s=t}^{\infty} W_{s}^{j}=\sum_{s=t}^{\infty}\left(\beta^{j}\right)^{s-t} E_{t}\left[u\left(c_{s}\right)+L_{s}+\mathbf{I}_{s} X_{s}-\mathbf{I}_{s-1} \mathbf{I}_{s} \xi_{s}\left(B_{s-1}^{*}-B_{s-1}\right)^{2}\right] \\
s=t, t+1, \ldots ; \quad j=a, b ; \quad \mathbf{I}_{r}= \begin{cases}1 & \text { if in power in period } r \\
0 & \text { otherwise }\end{cases}
\end{gathered}
$$

Everybody's expected consumption depends on expected after-tax income:

$$
E_{t}^{k}\left[c_{s}\right]=E_{t}^{k}\left[\left(1-\tau_{s}\right) \epsilon_{s} \bar{y}\right]=\left(1-\tau_{s}\right) \epsilon_{s}, \quad k=j, i .
$$

where $\tau_{s}$ is the tax rate. Period-specific expected growth factor shock $\epsilon_{s}$ captures the deviation from trend (or previous period or potential) output $\bar{y}$ which is normalized to $1 ; \epsilon_{s}>1$ is an expected boom; and $\epsilon_{s}<1$ is an expected recession.

The government's budget constraint relates primary deficit $D_{s}$ to the provision of (local) public goods $L_{s}$. It takes into account expected tax revenue $\tau_{s} \epsilon_{s}$ and the government's competence $\eta_{s}^{j}$ (see further down):

$$
L_{s}=\tau_{s} \epsilon_{s}+D_{s}+\eta_{s}^{j} .
$$

Excessive-debt municipalities are obliged to reduce their debts by a certain percentage every year and may have to impose a particularly high tax rate to do so. Low-debt municipalities do not face such requirements. In a continuous setting, we capture budget dynamics with two continuous functions. Every municipality's yearly (period-specific) debt target $B_{s}^{*}$ (which depends on the initial level of debt $B_{t-1}$ ) is

$$
\begin{aligned}
B_{s}^{*} & =\delta B_{s-1}^{*}, s=t, t+1, \ldots ; \text { with } B_{t-1}^{*} \equiv B_{t-1} ; \\
\delta & =\delta\left(B_{t-1}^{*}\right) ; 0<\delta \leq 1 \text { for } B_{t-1}^{*} \geq 0 ; \\
\delta(0) & =1 \text { and } \delta \text { monotonously decreasing. }
\end{aligned}
$$

We assume that the municipality's tax rate $\tau_{s}$ is predetermined and-as argued beforealso depends on the initial level of debt $B_{t-1}$, too:

$$
\tau_{s}=\tau=\tau\left(B_{t-1}\right) ; \quad \text { with } \tau^{\prime}>0 ; \tau^{\prime \prime}<0 .
$$

Given the interest payment on the inherited debt level $B_{s-1}$ from the previous period, and, possibly, debt reduction from $B_{s-1}$ to target level $B_{s}^{*}$ the government normally would be obliged to produce a primary surplus. Let's call it the primary surplus requirement (component 1) which would imply $D_{s}<0$ and require spending cuts. However, the government may choose to disregard the rules, especially in an election year, and maximize with respect to the second component, the freely choosable deficit $D_{s}^{\text {free }}$.

$$
\begin{aligned}
D_{s} & \equiv\left(B_{s}-B_{s-1}\right)-r B_{s-1} . \\
D_{s} & =\left(\left(B_{s}^{*}+D_{s}^{\text {free }}\right)-B_{s-1}\right)-r B_{s-1} ; \\
& =\underbrace{\left(B_{s}^{*}-B_{s-1}\right)-r B_{s-1}}_{\text {primary surplus requirement }}+\underbrace{D_{s}^{\text {free }}}_{\text {freely choosable }} ; \\
& =\delta B_{s-1}^{*}-(1+r) B_{s-1}+D_{s}^{\text {free }} .
\end{aligned}
$$


Table 1 The timing of events

\begin{tabular}{l}
\hline Time \\
\hline Period t \\
(1) Voters $i$ and incumbent $a$ observe: \\
the incumbent's last period skills $\mu_{t-1}^{a} ;$ \\
the predetermined tax rate $\tau_{t}$. \\
(2) Incumbent $a$ observes: \\
the temporary debt target $B_{t}^{*} ;$ \\
growth (estimate) $\epsilon_{t}$. \\
(3) Incumbent $a$ : \\
chooses primary deficit $D_{t} ;$ \\
thereby providing local public goods $L_{t}$. \\
(4) Voters $i$ observe: \\
local public goods $L_{t}$. \\
(5) Voters $i$ : \\
form expectations of the incumbent's current period skills $\widehat{\mu}_{t}^{a} ;$ \\
and vote. \\
The winner of the period $t$ elections takes office, receives an ego rent and suffers a repu- \\
tation loss, if she missed debt target $B_{t}^{*}$
\end{tabular}

As in Rogoff (1990), government competence is modelled as an MA(1) process. However, Shi and Svensson (2006) suggested that there new tasks always arise that do not allow candidates to know their own competencies $\eta_{s}^{j}$ in advance:

$$
\eta_{s}^{j}=\mu_{s}^{j}+\mu_{s-1}^{j}
$$

Shocks $\mu_{t}^{j}$ are random variables with mean 0 and distribution function $F\left[\mu_{t}^{j}\right]=F[\bullet]$. For simplicity, density function $f\left[\mu_{t}^{j}\right]=f[\bullet]=F^{\prime}[\bullet]$ is assumed to be bell-shaped, but more general specifications also would be possible. Inserting Eqs. (6) to (8) into budget constraint (4) we obtain:

$$
\begin{aligned}
L_{s} & =\tau_{s} \epsilon_{s}+D_{s}+\mu_{s}^{j}+\mu_{s-1}^{j} ; \\
& =\tau\left(B_{t-1}\right) \epsilon_{s}+\delta B_{s-1}^{*}-(1+r) B_{s-1}+D_{s}^{f r e e}+\mu_{s}^{j}+\mu_{s-1}^{j} .
\end{aligned}
$$

The timing of events is presented in Table 1. Elections take place in alternating periods. At the beginning of election period $t$, voters and incumbent $a$ observe the realizations of last period's skills shock $\mu_{t-1}^{a}$ and predetermined current period tax rate $\tau_{t}$. The incumbent also observes (period-specific) debt target $B_{t}^{*}$ and growth shock $\epsilon_{t}$ which allow her to decide on the optimal level of freely choosable deficit $D_{t}^{\text {free }}{ }^{4}$ On that basis, the government chooses

\footnotetext{
${ }^{4}$ Voters may or may not observe the debt target and the growth shock (whereas policymakers are assumed to observe the growth shock correctly). The model is silent (and this does not affect the qualitative results) on whether their beliefs about expected growth $\widehat{\epsilon}_{t}$ and expected primary deficit $\widehat{D}_{t}$ are determined on the basis of full or partial information, rationally or not. Those beliefs affect voters' expectations of the incumbent's current period skills $\widehat{\mu_{t}^{a}}$, but the incumbent can take them as given values only when choosing her optimal policy.
} 
the primary deficit level $D_{t}$, thereby providing quantity $L_{t}$ of local public goods. Voters observe $L_{t}$ and form expectations of skills shock, $\widehat{\mu_{t}^{a}}$, which is, however, affected by their expectations of the growth shock, $\widehat{\epsilon_{t}}$, and of the primary deficit, $\widehat{D_{t}}$. Voters base their decisions on whether to vote for the incumbent on $\widehat{\mu_{t}^{a}}$ because period $t$ skills affect the incumbent's competence in providing local public goods in $(t+1)$. Note that voters' expectations of the incumbent's competence can be mistaken for two reasons: (1) they may not be able to fully anticipate the incumbent's deficit policy; and (2) they may not be able to anticipate fully an imminent economic slump or boom.

In period $(t+1)$, the winner of the election receives ego rent $X$. Policy in $(t+1)$ no longer depends on voting, though; hence, either policymaker ( $a$ or $b$ ) will repay the costly debt to the extent possible, thereby cutting the provision of local public goods. ${ }^{5}$ Voters anticipate that response, but can do nothing to prevent it. Note also that the voting decision in election period $t$ does not extend to considering expected utility in $t+2$ because the MA(1) nature of the competence process makes incumbent and challenger indistinguishable then. Policymakers likewise do not account for $t+2$ in solving their optimization problem when determining the optimal level of $D_{t}^{\text {free }}$ because they cannot influence their own utility or boost their reelection chances in $t+2$. Hence, the model can be split into cycles of two periods consisting of election period $t$ and off-election period $(t+1)$.

\section{Model solution}

Given the timing of events and the reasoning for splitting the analysis into two-period election cycles the solution is found by studying the incumbent's utility maximization over the cycle, including the election period $t$ and off-election period $(t+1)$. Whether the incumbent receives an ego rent in period $(t+1)$ depends on the probability of being elected which, in turn, depends on her election year choice of the optimal level of deficit $D_{t}$, which ultimately depends on the choice of freely choosable deficit $D_{t}^{\text {free }}$. The logic of the model's solution is explained here, but details are provided in the Online Supplementary Material. Voters base their voting decisions in period $t$ on a comparison of utilities to be expected from the incumbent and the challenger in period $(t+1)$. The utility expected from the provision of local public goods in $(t+1)$ is affected by the policymakers' competence $\left(\eta_{t+1}^{j}=\mu_{t+1}^{j}+\mu_{t}^{j}\right)$ and individuals' expectations thereof. Since competence is an MA(1) process, incumbent $a$ 's period $t$ choice of $D_{t}^{\text {free }}$ affects what voters expect of the incumbent's competence in period $(t+1)$, whereas nothing is known about the challenger. In Online Appendix A we derive a (in our opinion, realistic) condition for a voter to vote for the incumbent, which already was hinted at when explaining Eq. (1). If the voter shares the incumbent's ideology and the incumbent is expected to do at least an equally good job $\left(E_{t}^{i}\left[\mu_{t}^{a}\right] \geq E_{t}^{i}\left[\mu_{t}^{b}\right]=0\right)$ or if the voter has a different ideology (though not too far on the other side of the political spectrum) and the incumbent does a great job, then the voter will vote for the incumbent:

\footnotetext{
5 We do, however, assume that the government never falls below the period-specific debt target. $B_{t+1}^{*}$ is, therefore, both the lower limit and the relevant debt target for period $(t+1)$. Theoretically, it could be optimal to reduce the debt level even further strategically in order to have more room for maneuver in the next election period $(t+2)$, although behavior of that kind may seem unrealistic, especially when the stock of debt is very high. By assuming the debt target to be the lower limit for debt reduction, we follow Shi and Svensson (2006); they also rule out strategic behavior by not allowing the government to produce negative debt.
} 


$$
E_{t}\left[\mu_{t}^{a}\right]>\alpha \theta^{i} .
$$

On that basis, the individual's probability of voting for the incumbent can be derived (see the end of Online Appendix A). The probability that the incumbent wins the election is, therefore:

$$
\operatorname{Prob}\left\{\left[\frac{E_{t}\left[\mu_{t}^{a}\right]}{2 \alpha}+\frac{1}{2}\right] \geq \frac{1}{2}\right\} \text {. }
$$

Voters extract government competence $\mu_{t}^{a}$ by relying on the public budget constraint (9). True competence is:

$$
\mu_{t}^{a}=L_{t}-\tau_{t} \epsilon_{t}-D_{t}-\mu_{t-1}^{a} .
$$

Voters can observe the level of local public goods $L_{t}$, the tax rate $\tau_{t}$, and previous period competence $\mu_{t-1}^{a}$. Their perception of government competence is, however, also affected by their expectations of growth and the government's budget deficit policy. Using Eq. 13 (see Online Appendix B) the perception of competence $E_{t}\left[\mu_{t}^{a}\right]$ can be expressed as:

$$
E_{t}\left[\mu_{t}^{a}\right]=\widehat{\mu_{t}^{a}}=L_{t}-\tau_{t} \widehat{\epsilon}_{t}-\widehat{D}_{t}-\mu_{t-1}^{a}=\mu_{t}^{a}+\left[\tau_{t}\left(\epsilon_{t}-\widehat{\epsilon}_{t}\right)\right]+\left[D_{t}-\widehat{D}_{t}\right] .
$$

Note that voters overestimate the incumbent's competence $\left(\widehat{\mu_{t}^{a}}>0\right)$, if the government can raise the primary deficit above what is expected by voters. This is the standard manipulation argument. However, if voters think the recession is less severe than it actually is, they underestimate the incumbent's competence.

Let us now rewrite the incumbent's probability of winning (12):

$$
\begin{aligned}
\operatorname{Prob}^{\text {win }} & =\operatorname{Prob}\left\{\left[\frac{\mu_{t}^{a}+\left[\tau_{t}\left(\epsilon_{t}-\widehat{\epsilon}_{t}\right)\right]+\left[D_{t}-\widehat{D}_{t}\right]}{2 \alpha}+\frac{1}{2}\right] \geq \frac{1}{2}\right\} \\
& =1-F\left[\tau_{t}\left(\widehat{\epsilon}_{t}-\epsilon_{t}\right)+\widehat{D_{t}}-D_{t}\right] .
\end{aligned}
$$

If we assumed rational expectations, no manipulation is possible in equilibrium and the probability of winning cannot be increased (despite the government's best efforts in doing so, as seen in first-order condition 17). Under other behavioral assumptions for voters' expectations, the probability of winning can be affected by the incumbent's choice. For the core result of the paper it does not matter whether the winning probability can be affected or not. We, therefore, take an agnostic point of view at this stage, but will discuss the effect of voters' assumptions when discussing Lemma 1 and Proposition 1 further down.

The incumbent's two-period maximization problem can now be written as follows (see end of Online Appendix B and Appendix C; $X_{s}$ is held constant and discount factor $\beta$ is set to 1 because it is irrelevant for the qualitative properties of the results):

$$
\begin{aligned}
& \max _{D_{t}^{\text {free }}} E_{t}^{a}\left\{u\left((1-\tau) \epsilon_{t}\right)+L_{t}+X\right\} \\
& \quad+E_{t}^{a}\left\{\operatorname{Prob}^{\text {win }}\left[u\left((1-\tau) \epsilon_{t+1}\right)+L_{t+1}+X-\left(B_{t}^{*}-B_{t}\right)^{2}\right]\right\} \\
& \quad+E_{t}^{a}\left\{\left(1-\operatorname{Prob}^{\text {win }}\right)\left[u\left((1-\tau) \epsilon_{t+1}\right)+L_{t+1}\right]\right\} ;
\end{aligned}
$$

where $L_{t}=\tau \epsilon_{t}+D_{t}+\eta_{t}^{j}$;

$$
\begin{aligned}
& L_{t+1}=\tau \epsilon_{t+1}+\left(\delta^{2}-(1+r)^{2}\right) B_{t-1}^{*}-(1+r) D_{t}+\eta_{t+1}^{j} ; \\
& D_{t}=(\delta-(1+r)) B_{t-1}^{*}+D_{t}^{\text {free }} .
\end{aligned}
$$


The first-order condition (FOC) determines the government's optimal choosable deficit $D_{t}^{\text {free* }}$ (because the second order condition for an optimum is satisfied):

$$
\begin{gathered}
\frac{\mathrm{d} V}{\mathrm{~d} D_{t}^{\text {free }}}=1-\left(1+r_{t}\right)+F^{\prime}\left[\tau\left(\widehat{\epsilon}_{t}-\epsilon_{t}\right)+\widehat{D_{t}}-(\delta-(1+r)) B_{t-1}^{*}+D_{t}^{\text {free }}\right] \\
{\left[X-\left(\delta B_{t-1}^{*}-B_{t}\right)^{2}\right]=0 ;} \\
\Leftrightarrow r_{t}=F^{\prime}[\bullet]\left[X-\left(\delta B_{t-1}^{*}-B_{t}\right)^{2}\right] .
\end{gathered}
$$

The FOC is staightforward. The interest rate (which is the net marginal loss from incurring a deficit) must be equal to the net marginal gain from increasing the chances of winning. The latter is the net benefit for the government (ego rent minus reputation loss) times the marginal increase in winning chances owing to the increase in voter-perceived governmental competence caused by the increase in deficit-financed public goods.

As the FOC defines the equilibrium for any expected growth rate $\epsilon_{t}$, we can now study the effect of (reduced or aggravated) boom or recessionary expectations:

\section{Lemma 1 Growth Expectations.}

Expectations of imminent boom (higher $\epsilon_{t}$ in Eq. 16) reduce the government's chosen optimal deficit $D_{t}^{\text {free* }}$ as well as the overall primary deficit $D_{t}$ in equilibrium. (Recessionary expectations raise it.)

$$
\begin{aligned}
& \text { (1) } \frac{\mathrm{d} D_{t}^{\text {free* }}}{\mathrm{d} \epsilon_{t}}=-\tau\left(B_{t-1}^{*}\right) \epsilon_{t}<0 ; \\
& \text { (2) } \frac{\mathrm{d} D_{t}}{\mathrm{~d} \epsilon_{t}}=\frac{\mathrm{d}\left[(\delta-(1+r)) B_{t-1}^{*}\right]}{\mathrm{d} \epsilon_{t}}+\frac{\mathrm{d} D_{t}^{\text {free }}}{\mathrm{d} \epsilon_{t}}=0-\tau\left(B_{t-1}^{*}\right) \epsilon_{t}<0 .
\end{aligned}
$$

\section{Proof Online Appendix D.}

The lemma says that a countercyclical policy effect materializes in election years. An opportunistic government will compensate for the tax revenue shortfall during the recession by an equal increase in the budget deficit. Conversely, an opportunistic government can reduce the deficit by the amount of additional tax revenue. The motivation is clear, the government does not give voters reason to believe that it would not be able to provide the same quantity of public goods with or without a recession or a boom. Recall that the optimal choice of public goods and, hence, of the deficit already is elevated as indicated by the first-order condition. The lemma says only that the government does not want to provoke a reduction in its competence as perceived by voters.

Lemma 1 can be illustrated in a stylized situation. Figure 1 captures a balanced budget situation, if output is at trend level. Situations to the left produce a budget deficit, those to the right a budget surplus. This is so because we assume that revenues are given by an upward-sloping straight line, which is determined purely by economic activity. For simplicity, no countercyclical (Keynesian) response to recessions is undertaken. Government expenditures do not respond to output; the government can change expenditures only discretionarily. Given that set-up, Lemma 1 simply says that an opportunistic government that expects a recession will not content itself with the "Normal PBC" (light [green] arrow) because it expects a revenue shortfall of the size of the 




Fig. 1 Expenditure and revenue

dark [green] arrow. It will, therefore, plan on compensating for the revenue shortfall by increasing the deficit so that the no-recession level of manipulated government services can be provided despite the expected economic downturn (in order to appear competent). The extent of manipulation overall will be the sum of both arrows.

It is important to note that the result of precisely compensating for the tax revenue shortfall was obtained on the basis of given voter expectations for growth, $\widehat{\epsilon}_{t}$, and deficit, $\widehat{D_{t}}$. If, for instance, voters were to expect a less severe recession than the government does, then the government would think that it will be harder to convince voters of its competence. Hence, the manipulation and the countercyclical policy effect would be strengthened. If, however, voters believed that the government would raise the deficit by less than the tax revenue shortfall, then it actually would be possible for an opportunistic government to increase the deficit by less. Hence, less manipulation would suffice and the countercyclical policy effect would be reduced. Analogous arguments could be made for expected booms. The factors determining the magnitude of the countercyclical policy effect already were studied by Bohn and Veiga (2017).

The focus of this paper is on how the countercyclical policy effect is influenced by the pre-existing debt level:

Proposition 1 Excessive Debt.

An increase in excessive debt reinforces the effect of growth expectations at the equilibrium.

$$
\frac{\mathrm{d} \frac{\mathrm{d} D_{t}}{\mathrm{~d} \epsilon_{t}}}{\mathrm{~d} B_{t-1}^{*}}=-\tau^{\prime}\left(B_{t-1}^{*}\right) \epsilon_{t}<0 .
$$

Proof Online Appendix D. 


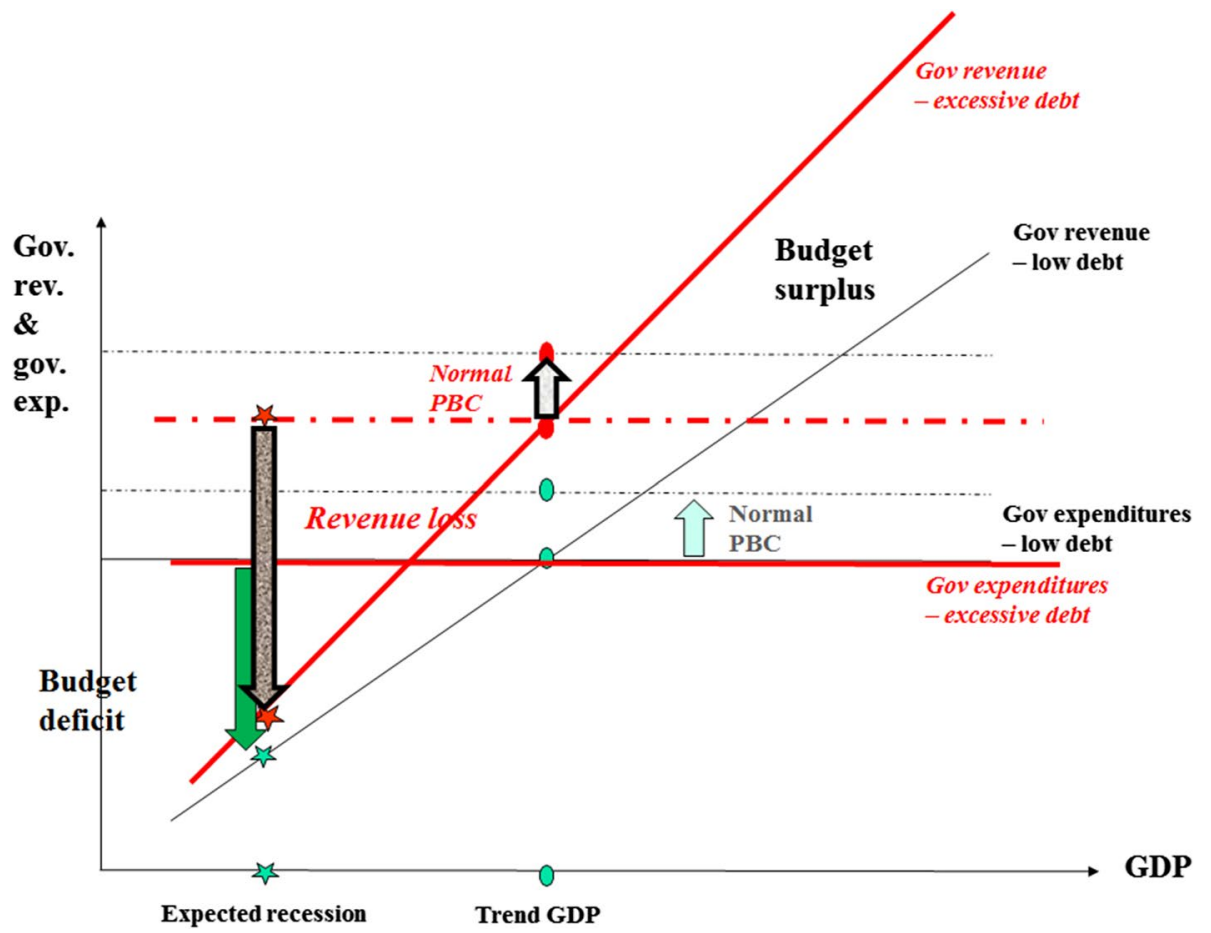

Fig. 2 Expenditure and revenue 2

The proposition says that opportunistic policymakers in governments with high initial stocks of debt will choose larger deficits in expected recessions and smaller deficits in expected booms compared to governments with lower debt levels, when they face an election. The proposition is a direct result of the countercyclical policy effect derived in Lemma 1, together with Eq. (6), which is, admittedly, a simple, but also a very plausible assumption, namely that tax rates are higher in high-debt entities. Even if the countercyclical policy effect were reduced for one of the aforementioned reasons, Proposition 1 still would hold. It captures the testable prediction that very indebted governments manipulate fiscal policy, in particular the primary budget deficit, more than governments with lower initial debt levels.

Proposition 1 can be illustrated in an analogous way. Figure 2 compares the situation of a low-debt and an excessive-debt municipality. The low-debt municipality is identical to the municipality of Fig. 1; thin lines and a normal text font are used. Our stylized excessive-debt municipality is different in two respects (fat lines and italicized text [all in red] are used). First, the government revenue line is steeper and above the line for the low-debt municipality. Second, at trend output a primary surplus is assumed to be used for debt repayment (for simplicity, we assume no debt repayment in the low-debt municipality). In normal times, the excessive-debt municipality likewise would experience a "Normal PBC" (light [textured] arrow with thick borders) at trend output. However, the expected revenue shortfall in case of a recession is much larger (dark [textured] arrow with thick borders). In order to appear competent, the no-recession level of manipulated government services must be provided despite the expected downturn. Hence, an 
excessive-debt municipality must increase the primary budget deficit by more than a low-debt municipality. The opportunistic countercyclical policy effect is thus larger. ${ }^{6}$

\section{Data, setting, and empirical model}

This section describes the data, the institutional setting for Portuguese municipalities, and the empirical model.

\subsection{Data and regional GDP growth forecasts}

The model's implication (Proposition 1) that the stock of public debt affects the way in which the government adjusts the primary deficit in response to economic performance (booms or recessions) is tested using data for Portuguese local governments. Municipal finance data were obtained from the Portuguese Directorate General of Local Authorities (DGAL), information regarding the dates of local elections and mayors' characteristics from the Ministry of Internal Affairs, and demographic and economic data from the National Statistics Institute (INE). GDP data are not available at the municipal (NUTS IV) ${ }^{7}$ level. Therefore, we collected data for the most disaggregated level available-NUTS III. Since data on municipal debt are available only since 2002, and data on regional GDP available from 1991 to 2014, our dataset covers the period from 2002 to 2014.

No GDP growth rate forecasts are made at either the municipal or the regional levels. National 1-year-ahead forecasts, produced by the Portuguese government, are available in the macroeconomic scenario of the national budget, which is presented to the Portuguese Parliament in October, shortly before the municipalities also must draft their budgets for the following year. Since the formula-determined transfers that municipalities receive from the central government are indicated in the national budget, the transfers must be taken into account when elaborating the municipal budgets.

Assuming that mayors form their expectations of next year's GDP growth rates based on the government's forecast of national real GDP growth, ${ }^{8}$ and information on their regions' current and past growth rates, we obtain 1-year-ahead forecasts estimating the following ARIMAX(2,0,1), i.e., ARMAX $(2,1) .{ }^{9}$ The model for the NUTS III GDP growth rates in each region is specified as

\footnotetext{
6 The average marginal election effects of total expenditures, discussed in footnote 19, suggest that the opportunistic policy effect might be even larger.

7 NUTS is the European Union's nomenclature for territorial statistical units. Portugal is subdivided into three NUTS I regions (Mainland, Azores and Madeira), seven NUTS II regions, and 25 NUTS III regions. Each NUTS III region aggregates several municipalities, which correspond to the NUTS IV level. Portugal has 308 municipalities, 278 on the mainland and 30 in the archipelagos of Azores (19) and Madeira (11).

8 The 1-year-ahead GDP growth forecasts from the IMF's World Economic Outlook (WEO) also are entered in robustness tests.

9 Short-run forecasts commonly are generated using ARIMA and ARIMAX models (see Enders 2014). ARIMA is a univariate time series model that uses autoregressive (AR) and moving average (MA) components of the dependent variable to explain or forecast its behavior. ARIMAX uses the AR and MA components jointly with a vector $\mathrm{X}$ of other explanatory variables. When the dependent variable is not stationary (i.e., integrated), it is necessary to take differences of it in the order of integration. The strategy suggested by Box and Jenkins (1976) is used to choose the most appropriate model. Since regional growth rates were found to be stationary, there is no need to take first-differences of the series. The ARMAX $(2,1)$ specification was the one found to be most appropriate for the majority of NUTS III regions.
} 


$$
\operatorname{RegGDP} P_{t}=\alpha_{0}+\alpha_{1} \operatorname{RegGDP} P_{t-1}+\alpha_{2} \operatorname{RegGDP} P_{t-2}+\alpha_{3} N a t G D P f_{t}+\zeta_{t}+\alpha_{4} \zeta_{t-1},
$$

where $\operatorname{RegGDP}$ is the real GDP growth rate for the region under scrutiny in year $t$, $N a t G D P f_{t}$ is the national real GDP growth forecast for year $t$ (obtained from the national budget for year $t$ ), and $\zeta_{t}$ is a white noise error term. The predicted values from the estimation of equation (18) for each of the 25 NUTS III regions ${ }^{10}$ are used in our empirical analysis as the regional growth forecasts. ${ }^{11}$

\subsection{Institutional setting of Portuguese municipalities}

Municipalities are the second highest government tier on mainland Portugal, just below the national government, and the third in the archipelagos of Azores and Madeira, where regional governments also are present. Regardless of their locations, all Portuguese municipalities are subject to the same laws and regulations, have the same institutional structure, and have the same responsibilities regarding public service provision: sewage, distribution of water, local transportation and communication, basic schooling, property maintenance, promotion of culture and science, recreation and sports facilities, local healthcare, social housing, environmental protection, and municipal policing. Regarding institutional structure, the Town Council (Câmara Municipal) holds the executive power, while the Municipal Assembly holds the legislative power, approving, among other things, the municipal budgets and activity plans. The members of both government branches are elected directly by citizens, who vote on closed party or independent lists of candidates. The top candidate on the list receiving most votes for the Town Council becomes the mayor, presides over that chamber and plays a leading role in the executive branch, having substantial power and autonomy.

Although the financial regime for local governments grants financial autonomy to municipalities, allowing them to elaborate and approve their own budgets without needing approval from a higher-ranked authority, the large majority of municipalities is depends heavily on grants from the central government or from the European Union (own revenues account, on average, for just one-third of total effective revenues). The municipal budget is drafted by the mayor's team, analyzed by the Town Council, and finally approved by the Municipal Assembly, in the last quarter of the year prior to the relevant fiscal year (which aligns with the calendar year). As $79 \%$ of the mayors are supported by majorities in both chambers (see Table E.2 in Online Appendix E), they can get their budgets approved easily. Municipalities are allowed to run budget deficits, but they are subject to limits regarding the stock of municipal debt. The current financial regime (Law n. 73/2013) stipulates that gross debt should not exceed 1.5 times the average current revenues of the last 3 years, and a municipality whose debt is above the legal limit is obliged to reduce the excess debt by $10 \%$ each year (which would correspond to $\delta=0.9$ in the theoretical model). If gross

\footnotetext{
10 The results of the estimation of the ARMAX model for each of the 25 Portuguese NUTS III regions are reported in Table E.1 in Online Appendix E.

11 The accuracy of the forecasts for the period considered in the estimations is as follows: mean error $(\mathrm{ME})=0.30$, mean absolute error $(\mathrm{MAE})=2.04$, root mean squared error $(\mathrm{RMSE})=2.65$. For the national forecasts: $\mathrm{ME}=0.87 ; \mathrm{MAE}=1.37 ; \mathrm{RMSE}=1.68$. Larger errors in regional forecasts were expected, since regional growth rates exhibit more volatility than national growth rates (the standard deviations are, respectively, 1.92 and 3.54). Regarding the correlation between actual and forecasted values, it is 0.66 for regions and 0.67 at the national level. Overall, the accuracy of the regional forecasts generated by the ARMAX models appears to be quite reasonable.
} 
debt is twice the legal limit, the municipality is forced to submit an adjustment plan to the Municipal Support Fund (Fundo de Apoio Municipal). ${ }^{12}$

Municipal elections were held for the first time in December 1976, following the military coup of 1974, which ended 48 years of dictatorship. Local elections were held every 3 years until 1985, and every 4 years thereafter (in December until 2001, and in October since then). Although national legislative elections sometimes occurred in the same year (at least three months apart, though), national, regional, or European elections never coincided with municipal elections.

\subsection{Empirical model}

The first result of the theoretical model regarding how the primary deficit responds to expected growth rates (Lemma 1) is tested with the following empirical model:

$$
D_{i, t}=\beta_{1} E l Y_{i, t}+\beta_{2} \operatorname{RegGDPf} f_{i, t}+\beta_{3}(E l Y * \operatorname{Reg} G D P f)_{i, t}+\mathbf{X}_{i, t}^{\prime} \omega+v_{i}+\sigma_{t}+\xi_{i, t},
$$

where $D_{i, t}$ is the primary budget deficit of municipality $i$ in year $t$ in real euros (of 2015) per capita; $E l Y_{i, t}$ is a dummy variable that equals one in municipal election years, and zero otherwise; $\operatorname{RegGDPf_{i,t}}$ is the forecast of real GDP growth for year $t$ in the region to which municipality $i$ belongs (estimated using the ARMAX model of Eq. 18); $\mathbf{X}_{i, t}$ is a vector of control variables which may affect budget balances; $v_{i}$ represents unobserved municipalityspecific fixed effects; $\sigma_{t}$ represents time-specific effects; ${ }^{13}$ and $\xi_{i, t}$ is the error term. The forecasted regional real GDP growth rate, $\operatorname{Reg} G D P f_{i, t}$ is interacted with $E l Y_{i, t}$, so that we can check whether the effects of expectations for economic growth in election years are different from those in the other years of the electoral cycle. ${ }^{14}$

Based on the theoretical model and on previous empirical evidence of PBCs in Portuguese municipalities (e.g., Bohn and Veiga 2017; Aidt et al. 2011; Veiga and Veiga 2007), we expect a positive $\beta_{1}$, consistent with larger budget deficits in election years. Additionally, a negative $\beta_{3}$ is expected, given the model's prediction that expected negative or unusually low growth rates lead to larger deficits, while positive growth rates lead to surpluses. The overall election-year effect on the budget balance is given by $\left(\beta_{1}+\beta_{3} * \operatorname{RegGDPf} f_{i, t}\right)$.

The vector $\mathbf{X}_{i, t}$ includes the following control variables, which may affect budget balances: dependency ratio; ${ }^{15}$ population density; dummy variables for left-wing and independent mayors; years in office (of the mayor); a dummy variable, Majority, which takes

\footnotetext{
${ }^{12}$ Legal debt limits varied over time, with successive versions of the local finance law. The choice of the limit currently in force is based on an exercise done in 2012 by the Technical Secretariat responsible for drafting the proposed revision of the Local Finance Law, of which one of the authors was a member. The idea was to determine the level of debt (relative to the level of current revenues) that, if surpassed at the beginning of the 2000 s, would lead clearly to excessive debt 10 years later. Thus, although the limit was not adopted during our entire sample period, it nevertheless can be used as reference for the definition of excessive debt. As a robustness check, other thresholds will be adopted in the empirical analysis.

13 Since the election-year dummy would be collinear with yearly dummy variables, we control for time effects using 5-year period dummies. In robustness tests, we also use 4-year mandate dummies and a cubic time trend.

14 A similar model was used in Bohn and Veiga (2017). However, there, the focus was on identifying a countercyclical policy effect in periods with recessionary expectations. Several dummies were employed to test the effect of recessionary expectations on the deficit.

15 The dependency ratio is the percentage of the population below 15 or above 65 years old. Population and population growth never were statistically significant when entered, and sometimes caused problems of collinearity.
} 
the value of one when the mayor is supported by majorities in both the Town Council and the Municipal Assembly, and zero otherwise.

An extended version of the model of Eq. (19) tests the theory's main prediction that a larger stock of municipal debt exaggerates the government's primary deficit response to expected booms or recessions (Proposition 1). The extended version can be presented as follows:

$$
\begin{aligned}
D_{i, t}= & \beta_{1} \text { ElY }_{i, t}+\beta_{2} \operatorname{RegGDPf}_{i, t}+\beta_{3} \text { ExcessDebt }+\beta_{4}(\text { ElY } * \text { RegGDPf })_{i, t} \\
& +\beta_{5}(\text { ElY } * \text { ExcessDebt })_{i, t}+\beta_{6}(\text { RegGDPf } * \text { ExcessDebt })_{i, t} \\
& +\beta_{7}(\text { ElY } * \text { RegGDPf } * \text { ExcessDebt })_{i, t}+\mathbf{X}_{i, t}^{\prime} \omega+v_{i}+\sigma_{t}+\xi_{i, t},
\end{aligned}
$$

where ExcessDebt ${ }_{i, t}$ is a dummy variable that takes the value of one if the gross debt of municipality $i$ in year $t$ is greater than 1.5 times the average current revenues of the last 3 years, and equals zero otherwise. The remaining variables are as described above. The models of Eqs. (19) and (20) will be estimated with fixed effects, with standard errors clustered by NUTS III region and year. Descriptive statistics of the variables used in this paper are presented in Online Appendix E (Table E.2).

\section{Empirical results}

Here, we present empirical results to test Lemma 1 and Proposition 1 of the theoretical model; we also discuss an array of robustness tests.

\subsection{Growth expectations}

The results of the estimation of the model of Eq. (19) for the primary deficit (in real euros per capita), by fixed effects, with standard errors clustered by NUTS III regions and years are reported in column 1 of Table 2 . In order to facilitate interpretation, the marginal effects for the election year, over the forecasted growth rates, are illustrated in Fig. 3. ${ }^{16}$ As predicted by Lemma 1 of the theoretical model, expected recessions (negative growth forecasts) in election years lead to even larger primary deficits, as local governments will not want to bear the electoral costs of reducing the provision of local public goods in order to compensate for lower tax revenues. The effect on the deficit is positive and statistically significant, except for $4 \%$ positive growth. That is, the primary deficit tends to be larger in election years than in the other years of the political cycle, for practically the entire range of predicted growth rates. That finding is consistent with the results of previous studies (e.g., Bohn and Veiga 2017; Aidt et al. 2011; Veiga and Veiga 2007), which likewise found evidence of political budget cycles in Portuguese municipalities.

The coefficient for regional real GDP forecasts is positive, indicating that primary deficits are reduced in non-election years when the economy is expected to slow down, which could be interpreted as precautionary fiscal policy. Note, however, that, as discussed in the next subsection, the coefficient is much reduced and becomes insignificant in the specification of column

\footnotetext{
${ }^{16}$ Since only about $1 \%$ of the distribution of forecasted growth rates is below $-6 \%$, and only another $1 \%$ is above 4\%, Fig. 3 only shows the marginal effects for forecasted growth rates within that interval.
} 
Table 2 Countercyclicality in PBCs

(1) (2) (3)

\begin{tabular}{|c|c|c|c|}
\hline Election year & $\begin{array}{l}61.968 * * * \\
(8.752)\end{array}$ & & $\begin{array}{l}62.903 * * * \\
(8.304)\end{array}$ \\
\hline Real GDP growth forecast (NUTS 3 region) & $\begin{array}{l}4.290 * * \\
(2.482)\end{array}$ & $\begin{array}{l}5.805^{* * *} \\
(2.496)\end{array}$ & $\begin{array}{l}1.166 \\
(0.694)\end{array}$ \\
\hline Election year $*$ Real GDP growth forecast (NUTS 3 region) & $\begin{array}{l}-14.569 * * * \\
(-5.387)\end{array}$ & $\begin{array}{l}-12.973 * * * \\
(-3.137)\end{array}$ & $\begin{array}{l}-7.974 * * \\
(-2.553)\end{array}$ \\
\hline Excess debt & & & $\begin{array}{l}23.219^{* *} \\
(2.557)\end{array}$ \\
\hline Election year * Excess debt & & & $\begin{array}{l}2.732 \\
(0.168)\end{array}$ \\
\hline Excess debt $*$ Real GDP growth forecast (NUTS 3 region) & & & $\begin{array}{l}8.976^{* * *} \\
(3.481)\end{array}$ \\
\hline $\begin{array}{l}\text { Election year * Excess debt } * \text { Real GDP growth forecast } \\
\text { (NUTS } 3 \text { region) }\end{array}$ & & & $\begin{array}{l}-17.149 * * * \\
(-2.937)\end{array}$ \\
\hline Mayor left & $\begin{array}{l}-14.473 \\
(-1.262)\end{array}$ & $\begin{array}{l}-12.727 \\
(-1.125)\end{array}$ & $\begin{array}{l}-12.258 \\
(-1.073)\end{array}$ \\
\hline Mayor independent & $\begin{array}{l}32.816 \\
(1.160)\end{array}$ & $\begin{array}{l}37.428 \\
(1.332)\end{array}$ & $\begin{array}{l}34.976 \\
(1.233)\end{array}$ \\
\hline Years mayor & $\begin{array}{l}-0.714 \\
(-1.201)\end{array}$ & $\begin{array}{l}-0.873 \\
(-1.318)\end{array}$ & $\begin{array}{l}-0.825 \\
(-1.393)\end{array}$ \\
\hline Majority & $\begin{array}{l}0.194 \\
(0.017)\end{array}$ & $\begin{array}{l}1.681 \\
(0.150)\end{array}$ & $\begin{array}{l}0.477 \\
(0.042)\end{array}$ \\
\hline Dependency ratio & $\begin{array}{l}-5.123^{*} \\
(-1.780)\end{array}$ & $\begin{array}{l}-2.876 \\
(-1.038)\end{array}$ & $\begin{array}{l}-4.307 \\
(-1.487)\end{array}$ \\
\hline Population density & $\begin{array}{l}0.037 \\
(1.030)\end{array}$ & $\begin{array}{l}0.048 \\
(1.314)\end{array}$ & $\begin{array}{l}0.035 \\
(1.019)\end{array}$ \\
\hline Election years-Non-election years & & $\begin{array}{l}52.656^{* * * *} \\
(7.982)\end{array}$ & \\
\hline Time effects controlled for using: & $\begin{array}{l}\text { 5-Year } \\
\text { Dummies }\end{array}$ & $\begin{array}{l}\text { Yearly } \\
\text { Dummies }\end{array}$ & $\begin{array}{l}\text { 5-Year } \\
\text { Dummies }\end{array}$ \\
\hline Number of Observations & 4002 & 4002 & 4002 \\
\hline R-squared & 0.118 & 0.129 & 0.124 \\
\hline
\end{tabular}

Regressions with fixed effects for municipalities and standard errors clustered by NUTS III region and year. T-statistics based on standard errors robust to heteroskedasticity and autocorrelation are in parentheses $* * * p<0.01, * * p<0.05, * p<0.1$

3 (where the effect is picked up by the interaction term with excessive debt municipalities). As for the control variables, only the dependency ratio is (marginally) statistically significant, with a negative sign, indicating - somewhat surprisingly - that larger population shares of younger and senior people are associated with smaller deficits. However, that variable also becomes insignificant in the specifications of columns 2 and 3 described below.

In column 2 of Table 2, we control for time effects with year dummies, instead of 5-year period dummies. That change has the drawback of forcing the exclusion of the dummy variable for the election year, but has the advantage of accounting for other events that may 


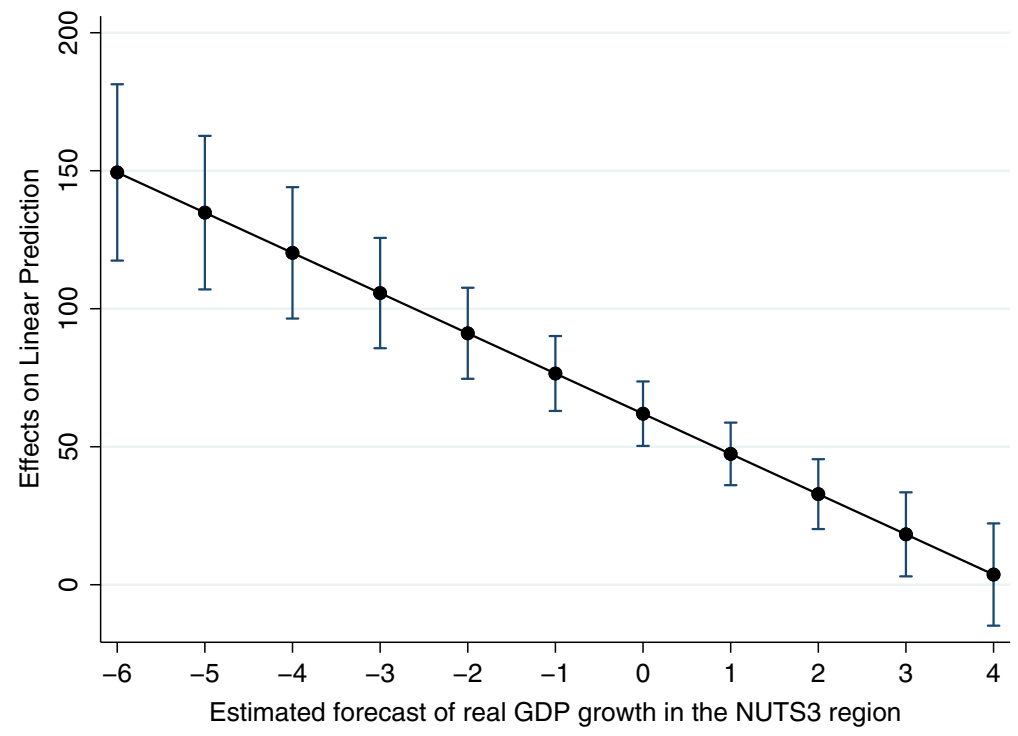

Fig. 3 Average marginal effects of the election year

have happened in specific election years. In order to economize on space, we do not report the coefficients for the year dummies. Instead, we test the hypothesis that the effects for election years are equal to those for non-election years. As shown towards the bottom of the table, the difference between election and non-election year effects is substantial (52.66 euros per capita) and statistically significant. Thus, our results are robust to controlling for time in that alternative manner (as well as to mandate dummies as discussed in the subsection on robustness tests further down).

\subsection{Excessive debt}

The results of the estimation of the model of Eq. (20), which takes the municipal debt stock into account, are reported in column 3 of Table 2. Since the interpretation of coefficients is not trivial when triple interactions are entered, the average marginal effects of the election year are illustrated in Fig. 4, for municipalities with and without excessive debt $($ ExcessDebt $=1$ and ExcessDebt $=0$, respectively $),{ }^{17}$ over the forecasted growth rates.

Both lines are negatively sloped, indicating a negative relationship between deficits and forecasted growth rates, as shown in Fig. 3. The larger slope of the marginal effects line for municipalities with excessive debt is consistent with the prediction made in Proposition 1 of the theoretical model, namely, that, in election years, voters are more sensitive to growth expectations than those in municipalities whose debt stocks are not excessive. ${ }^{18}$

\footnotetext{
17 The dummy variable ExcessDebt takes the value of one if the gross debt of the municipality exceeds the legal limit of 1.5 times its average current revenues over the previous 6 years, and equals zero otherwise.

18 This happens because municipalities with excessive debts tend to have higher tax rates and, therefore, suffer larger revenue losses during recessions than less-indebted municipalities. Although we do not have information on municipal tax rates for most of the sample period and, thus, cannot test the relationship directly, we show in Table E.3 in Online Appendix E that, regardless of the time horizon considered, fiscal revenue tends to increase more in high-debt municipalities (for which we estimate two specifications, either
} 


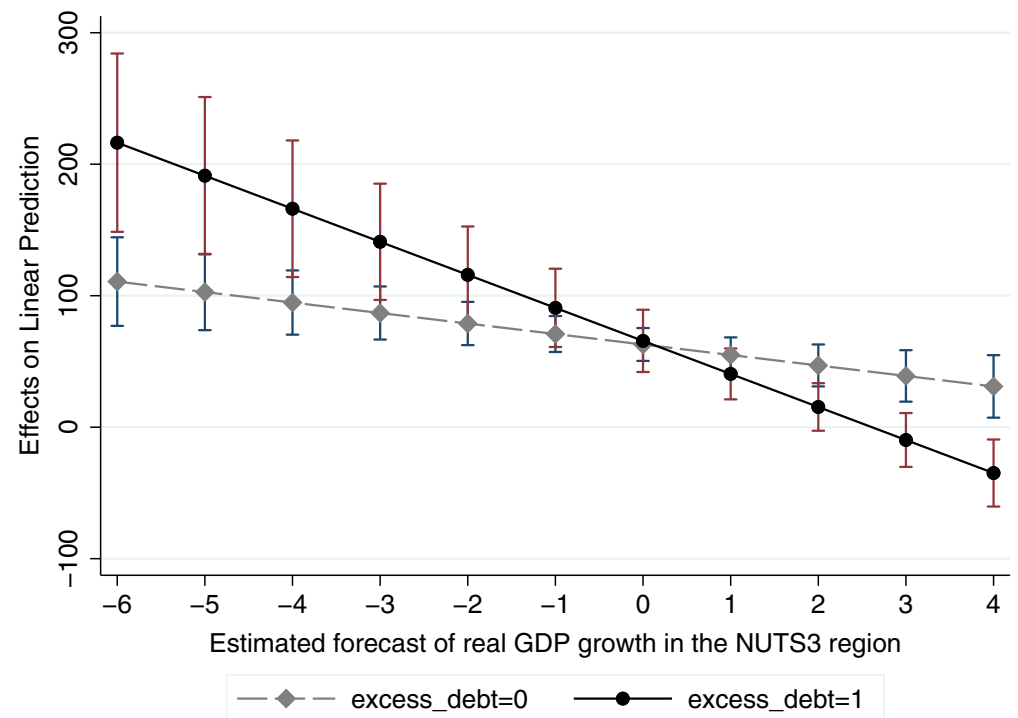

Fig. 4 Average marginal effects of the election year

That is, in an election year, excessive-debt municipalities register relatively larger primary deficits for more negative forecasted growth rates, while they have smaller deficits, or even surpluses, for higher growth rates. ${ }^{19}$ Only for expected growth rates between -1 and $1 \%$ it is not possible to reject the hypothesis that the primary deficit is the same for both types of municipalities.

The positive sign of the interaction term between excessive debt and the GDP forecast in column 3 of Table 2 may seem counterintuitive. It does, however, follow the precautionary policy logic discussed in the previous subsection. The positive coefficient means that in an excessive-debt municipality, a smaller deficit is run in an expected recession during an off-election year. Recession in an excessive-debt municipality implies a larger revenue loss (see also Footnote 18). Precautionary behavior then means extra cautious fiscal policy in an excessive-debt municipality.

In order to check for eventual non-linear effects of forecasted regional real GDP growth, we included a squared term in the model of Eq. (20). As shown in Fig. 5, the effects are similar to those obtained when accounting only for linear effects of forecasted regional GDP growth; and our conclusions remain essentially the same.

Footnote 18 (continued)

debt ratios in the initial period or the excessive debt criterion adopted throughout the paper, also as of the initial period).

19 The graphs of Figure F.1 in Online Appendix F suggest that, in excessive debt municipalities, the large deficits in election years during severe recessions are associated with both an increase in expenditures and a decline in fiscal revenues. 


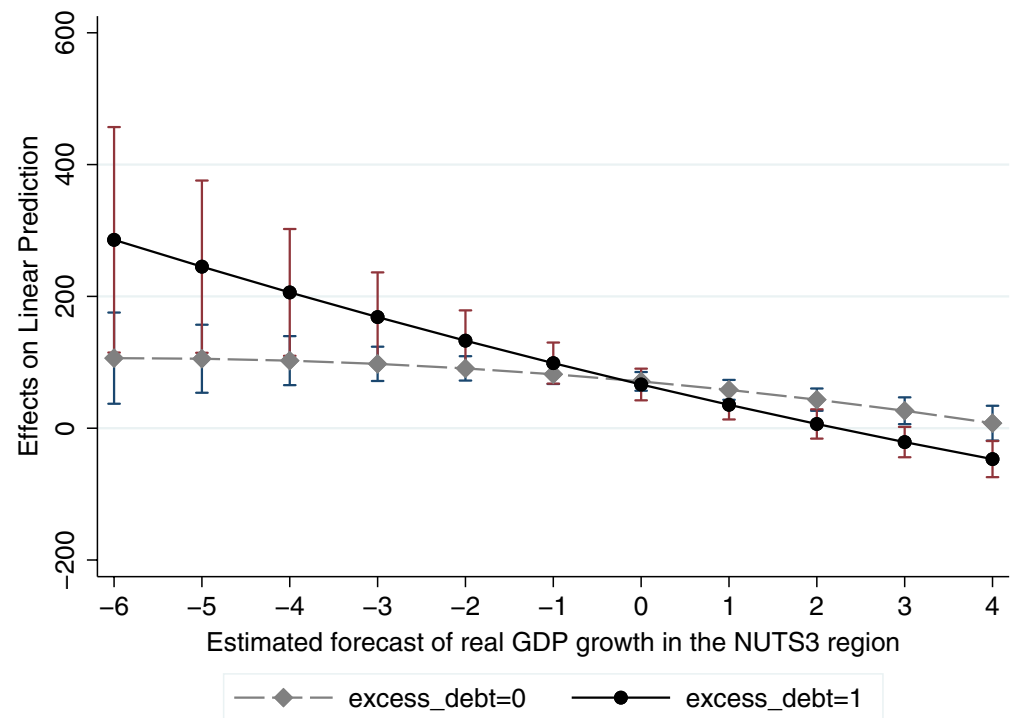

Fig. 5 Average marginal effects of the election year (non-linear GDP growth effects)

\subsection{Robustness tests}

The robustness of our main empirical results (column 3 of Table 2) was checked in several ways. ${ }^{20}$ First, we tried two different definitions of excessive debt: debt ratio above 2 (debt stock above twice the average current revenues of the last 3 years); and debt ratio above its sample median (1.3 times average current revenues of the last 3 years). The results, shown in Table F.1 in Online Appendix F are similar to those of Table 2, indicating that our results are robust to using alternative definitions of excessive debt.

Second, we checked the robustness of the results to minor respecifications: excluding vector X of control variables; controlling for time effects with 4-year mandate dummies (instead of 5-year period dummies); and clustering standard errors by municipality (instead of by region and year). Then, we checked if results changed when forecasts of national GDP growth rates were used instead of forecasts for growth in NUTS III regions. As shown in Table F.2 in Online Appendix F, the results remain practically the same as in column 3 of Table 2.

Finally, we also checked whether the results were sensitive to three sample restrictions: excluding the 30 municipalities of the archipelagos of Azores and Madeira, as they have regional governments; excluding 100 municipalities for which formula-determined grants from the central government exceed $50 \%$ of total revenues (excluding loans), as those municipalities' revenues are less sensitive to the business cycle than those of local governments that rely more on own revenues; and, excluding term-limited mayors (in our sample, a total of 160 , but only in the term leading up to the 2013 elections) as they have weaker incentives to behave opportunistically in election years. Again, the results, reported in Table F.3 in Online Appendix F, are similar to those of Table 2.

\footnotetext{
20 The robustness tests' results are shown in tables only. Nevertheless, the respective figures are similar to those shown above; they are available from the authors upon request.
} 


\section{Conclusion}

The goal of this paper was to show that it makes sense for policymakers of highly indebted local governments (e.g., countries, municipalities) facing an election to raise the primary budget deficit beyond what policymakers dealing with a smaller stock of debt will do, when faced with a recession (and vice versa for a boom). When tax rates are higher in high-debt entities, the tax revenue shortfall is more significant, but opportunistic policymakers will try to compensate for it in order to avoid giving the impression of being incompetent. We obtain robust support from our empirical investigation of Portuguese municipalities that recessions, elections, and high debt form an unholy trinity. That combination is shown to apply specifically to Portuguese municipalities, but the theoretical model illustrates that the underlying mechanism is more generally relevant.

Our finding is important because high-debt governments often face recessions and are thus tempted to manipulate fiscal policy more when elections are on the horizon. Such behavior may be particularly relevant for high-debt countries, because they often face both recessions and more frequent elections at the same time. Clear policy conclusions can be drawn from the theoretical mechanism we suggest. Rules and obligations for the government may not help much. Effective deficit and thus debt reduction may work only if voters can be made fully aware of the (expected) economic conditions; and if their expectations of government expenditures and services provisions can be lowered sufficiently. Such awareness reduces the magnitude of the competence-pretence game the government has to play.

Acknowledgements We would like to thank for helpful comments by participants of the NIPE and NiCE seminars at the Universities of Minho and Nijmegen, respectively, in the fall of 2017; and participants at the European Public Choice Society Meetings in Rome and the Silvaplana Workshop on Political Economy in Pontresina in the spring and summer of 2018. Francisco Veiga is thankful for the funding with COMPETE reference n. POCI-01-0145-FEDER-006683 (UID/ECO/ 03182/2013), with the FCT/MEC's (Fundação para a Ciência e a Tecnologia, I.P.) through national funding and by the ERDF through the Operational Programme on Competitiveness and Internationalization-COMPETE 2020 under the PT2020 Partnership Agreement.

OpenAccess This article is distributed under the terms of the Creative Commons Attribution 4.0 International License (http://creativecommons.org/licenses/by/4.0/), which permits unrestricted use, distribution, and reproduction in any medium, provided you give appropriate credit to the original author(s) and the source, provide a link to the Creative Commons license, and indicate if changes were made.

\section{References}

Aidt, T. S., \& Mooney, G. (2014). Voting suffrage and the political budget cycle: Evidence from the London metropolitan boroughs 1902-1937. Journal of Public Economics, 112, 53-71.

Aidt, T. S., Veiga, F. J., \& Veiga, L. G. (2011). Election results and opportunistic policies: A new test of the rational political business cycle model. Public Choice, 148, 21-44.

Alt, J. E., \& Lassen, D. D. (2006). Fiscal transparency, political parties, and debt in OECD countries. European Economic Review, 50(6), 1403-1439.

Block, S. A. (2002). Political business cycles, democratization, and economic reform: The case of Africa. Journal of Development Economics, 67(1), 205-28.

Bohn, F., \& Veiga, F. J. (2017). Political opportunism and countercyclical fiscal policy in election-year recessions. NIPE Working Paper 01/2017, University of Minho.

Box, G., \& Jenkins, G. (1976). Time series analysis, forecasting and control. San Francisco, CA: Holden Day.

Brender, A., \& Drazen, A. (2005). Political budget cycles in new versus established democracies. Journal of Monetary Economics, 52(7), 1271-1295. 
Brender, A., \& Drazen, A. (2008). How do budget deficits and economic performance affect reelection prospects? American Economic Review, 98(5), 2203-2220.

de Haan, J., \& Klomp, J. (2013). Conditional political budget cycles: A review of recent evidence. Public Choice, 157(3-4), 387-410.

Drazen, A. (2001). The political business cycle after 25 years. In B. S. Bernanke \& K. Rogoff (Eds.), NBER macroeconomics annual 2000 (Vol. 15, pp. 75-117). Cambridge and London: MIT Press.

Drazen, A., \& Eslava, M. (2010). Electoral manipulation via voter-friendly spending: Theory and evidence. Journal of Development Economics, 92, 39-52.

Enders, W. (2014). Applied econometric time series (4th ed.). Hoboken, NJ: Wiley.

Franzese, R. J, Jr. (2002). Electoral and partisan cycles in economic policies and outcomes. Annual Review of Political Science, 5, 369-421.

Hayo, B., \& Neumeier, F. (2017). Public attitudes toward fiscal consolidation: Evidence from a representative German population survey. Kyklos, 70(1), 42-69.

Lohmann, S. (1998). Rationalizing the political business cycle: A workhorse model. Economics and Politics, 10(1), 1-17.

Pelzman, S. (1992). Voters as fiscal conservatives. The Quarterly Journal of Economics, 57, 327361.

Rogoff, K. (1990). Equilibrium political budget cycles. American Economic Review, 80, 21-36.

Rogoff, K., \& Sibert, A. (1988). Elections and macroeconomic policy cycles. Review of Economic Studies, $55(1), 1-16$.

Schneider, C. J. (2010). Fighting with one hand tied behind the back: Political budget cycles in the West German states. Public Choice, 142, 125-150.

Schuknecht, L. (1996). Political business cycles and fiscal policies in developing countries. Kyklos, 49(2), $155-170$.

Schuknecht, L. (2000). Fiscal policy cycles and public expenditure in developing countries. Public Choice, 102(1-2), 115-130.

Shi, M., \& Svensson, J. (2006). Political budget cycles: Do they differ across countries and why? Journal of Public Economics, 90(8-9), 1367-1389.

Streb, J. M., Lema, D., \& Torrens, G. (2009). Checks and balances on political budget cycles: Cross-country evidence. Kyklos, 62(3), 426-447.

Veiga, F. J., Veiga, L. G., \& Morozumi, A. (2017). Political budget cycles and media freedom. Electoral Studies, 45, 88-99.

Veiga, L. G., \& Veiga, F. J. (2007). Political business cycles at the municipal level. Public Choice, 131, 45-64.

Vergne, C. (2009). Democracy, elections and allocation of public expenditures in developing countries. European Journal of Political Economy, 25(1), 63-77.

Publisher's Note Springer Nature remains neutral with regard to jurisdictional claims in published maps and institutional affiliations. 